Politica, Vol. 7, No. 1, Januari-Juni 2020

\title{
BAIAT DALAM KONTEKS KEPEMIMPINAN DI INDONESIA
}

\author{
Oleh: Ozi Setiadi \\ e-mail: ozisetiadi@gmail.com \\ Dosen Pemikiran Politik Islam IAIN Kudus
}

\begin{abstract}
Abstrak
Baiat dalam Konteks Kepemimpinan di Indonesia. Baiat adalah sebuah media pemersatu dukungan, baik dalam hal politik maupun lainnya. Ia mengalami perubahan dalam praktik sejarah Islam hingga kini. Penelitian ini bertujuan untuk menganalisa baiat dalam konteks Indonesia dengan melihat akar historis praktik baiat pada awal sejarah kepemimpinan Islam. Metode penelitian yang digunakan adalah analisis deskriptif. Hasil penelitian ini menunjukkan bahwa pada masa Nabi Muhammad Saw. dan al-khulafa ar rasyidun baiat diberikan dari rakyat pada pemimpinnya. Sebaliknya, pada konteks Indonesia baiat diberikan dari pemimpin pada rakyatnya. Baiat menjadi relevan dengan kondisi politik Islam Indonesia. Konsep baiat berbentuk sumpah/janji setia berbeda antara masa Rasul Saw. dan sahabat.
\end{abstract}

Keywords: Baiat, Kepemimpinan, Indonesia.

\section{A. Pendahuluan}

Muhammad Saw. merupakan pemimpin agama sekaligus pemimpin negara. ${ }^{1}$ Beliau mewariskan berbagai hal sebagai acuan dalam kehidupan umat Muslim. Ini tertuang dalam wahyu yang diturunkan oleh Allah yang mana beliau memiliki memiliki otoritas penuh atas tafsir wahyu tersebut. Dengan otoritas yang dimiliki oleh Rasulullah Muhammad Saw., ia menjadi Nabi terakhir yang berfungsi sebagai pemimpin agama. Sedangkan sebagai pemimpin negara ditandai dengan kesuksesannya dalam menggunakan wahyu dalam praktikkebernegaraan. Menyatukan kabilah-kabilah yang ada pada

\footnotetext{
${ }^{1}$ Hal pertama yang dilakukan oleh Nabi Muhammad SAW. di Madinah dalam rangka pembentukan sebuah negara adalah membuat Piagam Madinah pada tahun pertama Hijriyah. Piagam yang berisi 47 pasal ini memuat peraturan - peraturan dan hubungan antara berbagai komunitas dalam masyarakat Madinah yang majemuk. Di negara baru ini Nabi Muhammad SAW. bertindak sebagai kapala negara dengan Piagam Madinah sebagai konstitusinya.
} 
masyarakat Madinah dalam satu ikatan. ${ }^{2}$ Ikatan satu akidah Islam, juga ikatan dalam satu kenegaraan yang menjadikan Al-Quran dan beliau sendiri (hadits) sebagai sumber hukum/konstitusi kenegaraan. ${ }^{3} \mathrm{Hal}$ ini dianggap sebagai titik awal peradaban Islam yang mana peradaban itu terus mengalami pasang surut hingga kini.

Capaian yang terjadi pada masa Muhammad Saw. dibangun atas dasar sebuah agama dan gagasan baru yang dengan ikhlas menggabungkan iman dengan kekuasaan politik. Muhammad Saw. melakukan implementasi dari keimanan berdasarkan ajaran agama Tuhan. Ini didasarkan atas syariat yang dirancang untuk menetapkan aturan-aturan tentang moral, hukum, keyakinan dan ritual agama, perkawinan, janis kelamin, perdagangan dan masyarakat. Antony Black menyebut hal ini dilakukan demi satu tujuan, yakni menunjukkan bahwa konsep terdahulu telah gagal dalam bertahan dari masalahmasalah yang ada, meski didasarkan pada prinsip filantropi. ${ }^{4}$ Terlepas dari hal itu, kesuksesan yang dicapai oleh Muhammad Saw. adalah sebuah keberhasilan seorang Nabi atas umat, bukan sebagai orang biasa.

Salah satu keberhasilan yang dicapai oleh Muhammad Saw. adalah keberhasilannya menyatukan dukungan politik melalui media baiat (bai'ah) atau janji setia. Ini menjadi alat pemersatu politik bagi umat yang sudah masuk Islam pada masa itu. ${ }^{5}$ Dampaknya, janji setia lisan tidak hanya diucapkan, tetapi teraplikasi dalam bentuk ibadah,

2 Antony Black, PemikiranPolitik Islam, (Jakarta: Serambi,2006), 35. Masyarakat Madinah terdiri dari tiga kelompok, yakni kaum Muslimin yang berasal dari Muhajirin Mekah serta penduduk kaum Anshardari Madinah yang berasal dari suku Aws dan Khazraj; orang-orang Yahudi yang terdiri dari suku Bani Nadhir, Bani Quraizhah dan Bani Qainuqa' serta sisa-sisa suku Arab yang masih menyembah berhala (politeisme).

${ }^{3}$ Muhammad Iqbal, Fiqh Siyasah, (Jakarta: Gaya Media Pratama, 2007), cet. II, 33.

${ }^{4}$ Antony Black, Pemikiran Politik Islam, 36.

${ }^{5}$ Meski apa janji setia itu berisi tentang pernyataan tidak menyekutukan Allah, menyembah-Nya, dan meninggalkan perbuatan jahat serta mantaati Muhammad Saw. sebagai seorang Nabi. Baca juga Muhammad Iqbal, Fiqh Siyasah,32. Iqbal mencotohkan bai'ah al- 'aqabah sebagai salah satu contoh baiat. Ini terjadi pada satu tahun sebelum Muhammad Saw. hijrah. Tercatat dalam sejarah sebanyak 12 orang penduduk Yatsrib (nama kota Madinah sebelum diganti) melakukan baiat tersebut pada musim haji. Mereka menyatakan keislaman dan tunduk terhadap peraturan yang ada. 
muamalah, dan syariah. Lebih dari itu, peperangan sebagai wujud pertahanan dan keamanan menjadi konsekuensi logis atasnya.

Pada konteks modern, baiat kemudian berkembang. Tidak hanya berbicara pada tatanan peribadatan, melainkan telah termodifikasi sedemikian rupa. Janji setia atau dukungan itu terwujud dengan baik melalui sebuahsistem votting dalam pemilu. Sistem penyatuan dukungan ini terakomodir dalam demokrasi. One man, one vote, setiap orang berkesempatan yang sama untuk menyatakan dukungan pada siapa yang dianggap mampu untuk menjadi pemimpin. Tidak hanya bagi negara-negara Barat, tetapi juga negara berpenduduk mayoritas Muslim seperti Indonesia.

Indonesia menjalankan apa yang disebut oleh Montesque sebagai trias politica. Pemisahan kekuasaan dalam bentuk eksekutif, legislatif dan yudikatif telah terjadi sejak awal negara ini berdiri. Kekuasaan eksekutif berada di tangan presiden dan pemegang jabatan pemerintah di daerah. Legislatif berada di tangan legislator yaitu DPR-RI, DPRD tingkat I maupun tingkat II. Sedangkan yudikatif merupakan kekuasaan Mahkamah Agung (MA). Ketiga lembaga tinggi negara ini menjalankan peran, tugas dan fungsinya masing-masing. Akan tetapi, sebelum menjalankan hal itu, orang-orang yang berada pada lembagalembaga tersebut menyatakan sumpah atau janji setianya. Sumpah dan janji setia ini terformat dalam bentuk sumpah dan janji jabatan. Sedangkan pada masa Muhammad Saw. sumpah setia ini disebut dengan baiat.

Implementasi yang berbeda antara janji setia pada masa Muhammad Saw. dengan janji setia yang diucapkan oleh lembaga tinggi negara menjadi menarik untuk dibahas. Oleh karenanya, penelitian ini akan mengkaji lebih lanjut guna menganalisa tentang transformasi baiat pada masa Muhammad Saw. dan al khulafa ar rasyidun dalam konteks kepemimpinan di Indonesia.

\section{B. Pemaknaan Baiat}

Istilah baiat dalam Al-Quran disebutkan secara langsung oleh Allah Swt. Terminologi ini kemudian menimbulkan banyak pemaknaan. Pada Al-Quran surat Al-Fath [48]: 10, baiat diterjemahkan sebagai janji setia. Begitu pula pada ayat 18 dalam surat yang sama. ${ }^{6}$

6 "Sesungguhnya orang-orang yang berbaiat (berjanji setia) kepadamu, mereka berjanji setia kepada Allah. Tangan Allah di atas tangan mereka, maka barangsiapa yang melanggar janjinya, niscaya akibat melanggar janji itu akan menimpa dirinya 
Sedangkan dalam hadis, baiat tercantum dalam hadis diantaranya diriwayatkan oleh imam Bukhari dan Muslim. ${ }^{7}$ Melalui dua landasan normatif ini dapat dipahami bahwa istilah baiat memang sudah dipakai sejak zaman Muhammad Saw. dan generasi sesudahnya. Kini istilah tersebut digunakan juga pada konteks kepemimpinan, baik kepemimpinan agama maupun kepemimpinan negara. Sebagaimana pula yang tercantum dalam kamus besar bahasa Indonesia (KBBI) yang mana baiat dimaknai sebagai pengucapan janji setia kepada imam (pemimpin). ${ }^{8}$ Ibrahim Jindan menyebut bahwa baiat tidak hanya melibatkan dua belah pihak, pemimpin dengan yang dipimpin. Lebih dari itu, terdapat pihak lain seperti ulama yang berfungsi sebagai konsultan dalam proses baiat, serta semua pihak yang bersangkutan,berbakat, berpengaruh dan mempunyai kekuasaan juga turut terlibat dalam proses itu. ${ }^{9}$ Olehkarenanya, meskipun baiat merupakan sebuah kata yang singkat, namun pemaknaan dan implementasinya melibatkan berabagai unsur.

Ibnu Khaldun mengemukakan baiat merupakan perjanjian untuk taat.Orang yang berbaiat atau orang yang berucap sumpah setia kepada pemimpinnya akan menyematkan pandangan-pandangan yang diembannya dari pemimpin, baik berupa perintah yang disenangi maupun yang tidak disenangi." ${ }^{10}$ Sedangkan Hasbie Ash-Shiddieqy memiliki pendapat yang berbeda. Menurunya, baiat merupakan sebuah bentuk pengakuan ummat untuk mematuhi dan mentaati imam.Ini dilakukan oleh ahlul halli wal aqdi dan dilaksanakan sesudah

sendiri dan barangsiapa menepati janjinya kepada Allah, maka Allah akan memberi pahala yang besar." (Al-Fath [48]: 10) "Sesungguhnya Allah telah ridha terhadap orang-orang mukmin ketika mereka berjanji setia kepadamu di bawah pohon, maka Allah mengetahui apa yang ada di dalam hati mereka lalu menurunkan ketenangan atas mereka dan memberi balasan kepada mereka dengan kemenangan yang dekat (waktunya)" (Q.S. 48 : 18)

7 "Dan Jarir bin Abdullah ra.Iaberkata: akuberbai'at kepada Rasulullah SAW. Untuk selalu mendirikan shalat, mengeluarkan zakat dan memberi nasihat terhadap setiap muslim” (H.R. Bukhari-Muslim).

8 Departemen Pendidikan dan Kebudayaan, Kamus Besar Bahasa Indonesia, (Jakarta: Balai Pustaka, 1995), cet. IV

${ }^{9}$ Khalid Ibrahim Jindan, TeoriPilitik Islam: Telaah Kritis Ibnu Taimiyah Tentang Pemerintahan Islam. Terj dari judul aslinya The Islamic Theory Of Govermen According to Ibn Taymiyah ( Surabaya : RisalahGusti, 1999), h. 95

${ }^{10} \mathrm{Ka}$ 'bi, Bai'at, h. 44. 
permusyawaratan. ${ }^{11}$ Artinya, terdapat lembaga yang memiliki otoritas dalam proses baiat tersebut. Ini menjadi pertanda transformasi dalam perkembangan perjalanan baiat itu sendiri. Berawal dari sesuatu yang tradisional kemudian berkembang menjadi dalam sebuah konsep politik modern yang melibatkan kelembagaan.

Berdasarkan penjelasan di atas, maka dapat ditarik benang merah bahwa baiat merupakan sebuah proses yang terjadi sebelum seorang pemimpin menjadi pemimpin atas yang dipimpin olehnya. Baik pemimpin maupun yang dipimpin berucap janji setia. Ikhlas dalam mengikuti sebuah aturan yang menyenangkan atau memberatkan mereka.

\section{Baiat dalam Sejarah Awal Islam}

Baiat merupakan salah satu alat pemersatu umat, khususnya pada masa Muhammad Saw. dan al khulafa ar rasyidun. Ini menjadi sebuah alat penyatu baik dalam tatanan aqidah mapun politik. Secara aqidah, umat yang berbaiat menyatakan diri akan mematuhi segala ketentuan yang ada dalam Islam. Mereka akan menghambakan dirinya kepada Allah, meninggalkan segala bentuk perbuatan jahat, dan mengikuti segala petunjuk yang diberikan oleh Muhammad Saw. ${ }^{12}$ Konsekuensi atas baiat itu umat akan menjalankan apa yang tertuang dalam rukun iman dan rukun Islam. Sedangkan dalam tatanan politik, umat menyerahkan sebagian haknya untuk diatur sesuai dengan ketentuan yang ada. Meminjam istilah Thomas Hobbes (1588-1679 M) dan Jhone Locke $(1632-1704 \mathrm{M}){ }^{13}$ ini berarti telah terjadi kontrak sosial yang manarakyat sepakat untuk memberikan sebagian haknya kepada pemimpin untuk diperintah dan diatur kehidupannya agar terjamin kebebasannya. Sebagai kompensasi atas hal ini, pihak pemimpin harus

11 T.M Hasbi Ash Shidieqy, Asas-asasHukum Tata Negara Menurut Syariat Islam (Yogyakarta : MatahariMasa, 1996), h. 66.

${ }^{12}$ Muhmmad Iqbal, Fiqh Siyasah, 32. Contoh konkrit baiat tentang hal ini adalah peristiwa bai'at al-'Aqabah. Ini adalah sebuah peristiwa yang di dalamnya terdapat ucapan dan sumpah setia yang dilaksanakan di Bukit Aqabah. Sebanyak 12 orang penduduk Yastrrib mengikrarkan diri kepada Muhammad untuk tidak menyekutukan Tuhan, tidak mencuri, tidak berzina, tidak membunuh anak-anak, tidak mengumpat dan memfitnah, baik di secara terang-terangan atau tersembunyi. Juga tidak menolak untuk berbuat kebaikan. Abu Abdullah Muhammad Ibn Sa'ad, Purnama Madinah, (Bandung: Al-Bayan, 1997), 11.

13 Baca Ahmad Suhelmi, Pemikiran Politik Barat: Kajian Sejarah Perkemabangan Pemikiran Negara, Masyarakat, dan Kekuasaan, (Jakarta: PT. Gramedia Pustaka, 2001), cet. II, 165-174 dan 181-205. 
dapat melaksanakan kewajibannya untuk melindungi dan mengayomi rakyat. ${ }^{14} \mathrm{Hal}$ yang demikian ini salah satunya tertuang dalam sebuah perjanjian yang dikenal dengan Piagam Madinah.Isi piagam ini telah disepakati oleh penduduk Madinah,baik muslim maupun tidak,untuk mendapatkan perlindungan dan keadilan yang sama berdasarkan pada undangundang yang disepakatibersama.

Tak bisa dipungkiri bahwa baiat,lebih jauh, dapat menjadi sebuah media perekat ikatan dalam bentuk solidaritas. Solidaritas seagama dan senegara.Keduanya memiliki hubungan simbiosis tersendiri. Lebih dari sekedar ikatan komunal, etnis, bahkan keluarga sekalipun.Baiat dalam hal keagamaan memberikan dampak terhadap pengekangan keganasan individual. Meminimalisir semangat persaingan yang tidak sehat, perasaan iri antar sesama, dan memberikan pandangan atas tujuan yang sama, yakni mendapat ridha dari Allah Swt. Sedangkan negara menjadi wadah pembentuk solidaritas yang memberikan kenyamanan rakyat. Melalui berbagai peraturan yang menertibkan, sehingga mendorong semangat lahirnya nasionalisme yang pada akhirnya rakyat memiliki "kewajiban moral" untuk melindungi negaranya tanpa memandang latar belakang apa pun.

Sejarah telah mencatat, setelah Muhammad Saw. wafat, tradisi baiat kemudian dilanjutkan oleh para sahabat. Mereka adalah al khulafa ar rasyidun. Tradisi ini bahkan dilanjutkan sebelum pemakaman beliau. M. Ayoub menceritakan betapa baiat untuk mendapatkan dukungan dari berbagai pihak itu terjadi sepeninggal Muhammad Saw.Seorang sahabat bernama Al-Abbas pergi menemui Abu Bakr dan Umar. Ia menanyakan apakah sepeninggal Muhammad Saw. terdapat perintah tertentu berkaitan dengan suksesi kepemimpinan, yakni masalah khilafah. Keduanya sepakat bahwa Nabi tidak menyatakan sesuatu tentang itu. Pertanyaan yang sama juga ditanyakan kepada 'Ali bin Abi Thalib, bahkan Al-Abbas oleh M. Ayoub disebut telah mengawali baiat terhadap Ali:

"Bentangkan tanganmu agar saya dapat memberikan baiat kepadamu sehingga masyarakat akan berkata, "Paman rasulullah telah membaiat sepupu rasulullah." Lalu, keluargamu sendiri akan memberikan baiat dan seluruh masyarakat akan

${ }^{14}$ G.H. Sabini, A History of Political Thought, dalam Muhmmad Iqbal, Fiqh Siyasah, 38. 
Politica, Vol. 7, No. 1, Januari-Juni 2020

mengikuti ajakan itu.'Ali bertanya, "akankah seseorang bertengkar akan masalah ini?",15

Proses suksesi dalam baiat ini menjadi sebuah diskusi panjang yang banyak diulas oleh para sejarawan. Perdebatan panas antara kaum Muhajirin dengan kaum Anshar terjadi terkait dengan hal ini. Kaum Muhajirin yang pada waktu itu termasuk Abu Bakar As Shiddiq dan Umar bin Khattab berdiskusi dengan kaum Anshar. Terjadi tarikmenarik dalam persoalan kepemimpinan. Kaum Muhajirin sebagai "kelompok pendatang" beranggapan lebih berhak atas kepemimpinan sepeninggal Rasul Saw. setidaknya ada dua alasan yang kuat mengapa mereka beranggapan demikian. Pertama, mereka yang lebih dahulu memeluk Islam. Kedua, mereka yang menemani Rasul Saw. hijrah dari kota Mekah ke Yatsrib (Madinah). Dua alasan ini tak terbantahkan, namun kaum Anshor juga memiliki argumentasi lain bahwa merekalah yang menerima kaum Muhajirin untuk hijrah ke Madinah. Silang pendapat ini kemudian menemukan titik temu, yang mana kaum Anshor kemudian memahami bahwa kaum Muhajirin merupakan kaum yang paling berjasa dalam penyebaran Islam. Kelapangandada ini juga dikuatkan dengan adanya pembagian kekuasaan sebagai sebuah solusi yang dimunculkan. ${ }^{16}$ Akhirnya, baik Muhajirin maupun Anshor, mendapatkan posisi-posisi strategis dalam pengelolaan negara Madinah.

Pembagian kekuasaan yang dilakukan sebagai sebuah solusi membuat perdebatan suksesi tidak berujung pada pertikaian. Umar bin Khattab adalah sosok yang paling berperan dalam hal ini. Beliau memunculkan konsep umara dan wizara. Kaum Muhajirin sebagai umara (pemimpin), sedangkan kaum Anshar sebagai wizara (menteri). Akhirnya, kedua belah pihak sepakat dan kemudian berbaiat kepada Abu Bakar, meski kaum Muhajirin yang hadir pada diskusi itu berbaiat kepada Abu Bakar tanpa 'Ali bin Abi Thalib yang masih disibukan dengan pengurusan jenazah Rasul Saw. Sebaliknya, kaum Anshar bersepakat untuk menjadikan Abu 'Ubadah bin al-Jarrahsebagai pemimpin, dan Abu Bakar sendiri meminta para pendukungnya untuk

${ }^{15}$ Mahmoud M. Ayoub, The Crisis of Muslim History, (Bandung: Mizan, 2004), 42.

${ }^{16}$ Pembagian kekuasaan ini merupakan cikal bakal 'trias politica' dalam Islam, sebuah konsep yang dicetuskan oleh Montesque. Konsep ini menjelaskan bahwa kekuasaan tidak bertumpu pada satu orang, melainkan dibagi dengan badan yang sama kuat, atau mendekati. 
membaiat Abu 'Ubadah dan Umar sebagai pemimpin, namun keduanya menolak dengan hormat. ${ }^{17}$

Penolakan yang disampaikan oleh keduanya menjadikan Abu Bakar kokoh dipilih sebagai pemimpin pada saat baiat di Saqifah. Argumentasi yang kuat yang menyebabkan Abu Bakar dipilih sebagai pemimpin pengganti Rasul Saw. adalah karena beliau yang menggantikan Rasul Saw. sebagai pemimpin Muslim saat salat ketika Rasul Saw. dalam keadaan sakit. Hal ini yang menyebabkan mereka yang hadir pada waktu itu sepakat untuk berbaiat kepada Abu Bakar, karena mereka berikrar baiat pada orang yang paling disukai oleh Rasulullah Saw. Umar memulai baiat tersebut dan diikuti oleh kaum Muhajirin dan Anshar yang ada pada waktu itu. Tidak ada pertentangan atasnya, sebab hal ini lebih melukiskan kehendak Rasul Saw. ${ }^{18}$

Mayoritas kaum Muhajirin dan Anshor sepakat dan berbaiat kepada Abu Bakar, kecuali ahl al bait Rasul Saw. Al-Zubair (sahabat dan sepupu Nabi yang terkenal) dan Banu Hasyim menolak memberikan baiat, sehingga secara terpaksa membaiatnya. Sebab dengan terpilihnya Abu Bakar membuat hak ahl al bait terampas. Ibn Qutaibah melaporkan ketika digiring ke hadapan Abu Bakar, 'Ali bin Abi Thalib protes. 'Ali berkata bahwa ahl al bait adalah yang paling berhak atas Rasul Saw. hidup atau mati. ${ }^{19}$ Artinya, suksesi kepemimpinan sepeninggal beliau menjadi hak mutlak ahl al bait. Ketika Abu Bakar tetap memegang jabatan itu, maka ia dianggap telah merampas hak tersebut. 'Ali bersama Al-Zubair dan keluarga Banu Hasyim menarik diri ke rumah Fathimah. 'Umar mengikuti dan mengancam akan membakar rumah itu jika orang-orang yang di

${ }^{17}$ Keinginan Abu Bakar agar para pendukungnya memilih satu diantara dua orang tersebut banyak menimbulkan perdebatan dan timbul suara-suara ribut dan keras. Salah satunya adalah kekhawatiran muncul pertentangan akibat ini. Meski Abu Bakar mengangkat tangan kedua orang tersebut sambil ia duduk diantara keduanya, namun tetap Abu Bakar yang dipilih sebagai pemimpin. Baca Muhammad Husein Haikal, Sejarah Hidup Muhammad, Penj. Ali Audah, (Jakarta: LiteraAntar Nusa, 2005), cet. XXX, 592.

${ }^{18}$ Muhammad HuseinHaikal, SejarahHidup Muhammad, 592 dan Mahmoud M. Ayoub, The Crisis of Muslim History, 44. Selain alasan senioritas, dan keutamaannya dalam Islam yang dituangkan dalam Al-Quran surat At Taubah [9]: 40 yang menerangkan tentang peristiwa kebersamaan Abu Bakar dengan Rasul Saw. saat hijrah dan berada di Gua Hira juga terdapat doktrin dalam hadis yang berbunyi "Barang siapa mati tanpa berbai'at (kepada imam), maka dia mati dalam kejahiliahan". (HR. Muslim no. 1851).

${ }^{19}$ Mahmoud M. Ayoub, The Crisis of Muslim History, 51. 
dalamnya menolak keluar dan memberikan baiat. Mereka semua keluar, kecuali 'Ali. 'Ali dan semua keluarga Hasyim baru membaiat Abu Bakar setelah wafatnya Fathimah, meskipun sejarahwan tidak sepakat mengenai tahunnya yang pasti. ${ }^{20}$

Sekitar dua tahun kepemimpinan Abu Bakar, suksesi kembali mengemuka, terlebih ketika ia jatuh sakit. Namun, ini tidak berlangsung lama sebab Abu Bakar menunjuk Umar sebagai penggantinya. Dalam kacamata politik penunjukan Umar sebagai Pengganti Abu Bakar menjadi hal yang sangat wajar mengingat Umar adalah pendukung utama pada saat suksesi kepemimpinan Abu Bakar. Akan tetapi, kemunculan nabi-nabi palsu, orang-orang murtad dari Islam, dan penolakan untuk membayar zakat membutuhkan pemimpin yang tegas seperti Umar. Penunjukan Umar sebagai khalifah pengganti Abu Bakar pun menjadi alasan yang logis karena adanyaperistiwa tersebut. Penduduk Madinah punjuga membaiat Umar mengikuti kehendak khalifah (Abu Bakar).

Pasca Abu Bakar wafat, Umar berhasil melakukan tata kelola pemerintahan dengan baik. Ini dimulai dengan pengelolaan keuangan melalui bait al maal. Ia tidak memberikan secara langsung ghanimah (harta rampasan perang) pada orang yang mengaku masuk Islam dengan niat mendapat zakat. Ia jugamembentuk sebuah lembaga yang bertugas untuk membahas mengenai suksesi setelahnya kelak. ${ }^{21}$ Umar membentuk lembaga syura yang terdiri dari enam orang formatur. Mereka adalah 'Ali bin Abi Thalib dan Utsman bin Affan, dua keturunan Abdul Manaf - datuk bagi marga Umayyah dan Hasyim dan dua menantu Nabi; Abd Al-Rahman Ibn 'Auf dan Sa'ad ibn Abi Waqqash, Paman Nabi dari pihak ibu; Zubair Ibn Al-Awwam, sepupu Nabi; Thalhah ibn Abd Allah, yang oleh Nabi disebut 'Thalhah yang baik'. ${ }^{22}$ Lembaga yang dibuat oleh Umar ini merupakan lembaga independen yang tidak dapat dicampuri oleh Umar dalam pemilihan khalifah penggantinya kelak.

Ketika Umar wafat, suksesi kepemimpinan ditangani oleh lembaga syura bentukannya. Terpilihlah Utsman bin Affan melalui dewan syura. Dengan keterpilihan Utsman melalui dewan syura tersebut, maka secara otomatis rakyat akan ikut serta membaiatnya sebagai

${ }^{20}$ Mahmoud M. Ayoub, The Crisis of Muslim History, 54.

21 Lembaga inilah yang diyakini sebagai contoh nyata dari cikal bakal terbentuknya dewan perwakilan rakyat.

${ }^{22}$ Mahmoud M. Ayoub, The Crisis of Muslim History, 82. 
pemimpin karena dalam lembaga itu terdiri dari orang-orang yang mewakili unsur-unsur kabilah pemegang kepentingan yang ada.

Kepemimpinan Utsman berlangsung sekitar dua belas tahun. Enam tahun pertama terjadi banyak kemajuan, seperti kodifikasi Al-Quran menjadi satu mushaf yang disebut sebagai Rasam Utsmani, dan lainnya. Akan tetapi, enam tahun berikutnya terjadi kemunduran. Faktor usia menjadi salah satu penyebab. Hal ini kemudian banyak dimanfaatkan oleh keturunan Bani Umayyah untuk mendapatkan posisi-posisi strategis dalam pemerintahan dan melakukan korupsi di dalamnya. Akibatnya, banyak orang yang tidak menyukai Utsman karena kesalahan-kesalahan keluarganya. Ini pula yang menyebabkan Utsman terbunuh pada saat pengepungan dirinya.

Sepeninggal Utsman, 'Ali terpilih menjadi khalifah. Banyak faktor yang menyebabkannya terpilih. Namun, faktor utama keterpilihan itu diantaranya adalah kekhawatiran munculnya fitnah sepeninggal Utsman dan 'Ali merupakan kandidat yang paling layak diantara dewan syura yang masih hidup. Sejarawan sepakat bahwa 'Ali terpilih secara aklamasi. Baiat terbuka di mesjid dengan kesepakatan seluruh hadirin memubuat 'Ali menjadi satu-satunya khalifah pengganti Rasul Saw. yang terpilih secara umum. Thalhah dan Al-Zubair termasuk orang yang pertama yang berbaiat kepada 'Ali dan menjamin baiat seluruh kaum Muhajirin. ${ }^{23}$ A Ali kemudian menjadi khalifah pengganti Utsman dan menjalankan roda pemerintahan sekitar dua tahun. 'Ali pun adalah khalifah keempat yang mendapatkan baia tsebelum kepemimpinan Islam berubah menjadi monarki.

Berdasarkan pemaparan di atas, maka dapat dipahami bahwa baiat yang ada pada awal sejarah Islam terjadi secara langsung dan delegatif. Artinya, setiap pengangkatan pemimpin, para sahabat dibaiat oleh tokoh-tokoh yang ada dalam satu kaum kemudian diikuti oleh rakyat secara luas. Sedangkan baiat pada masa 'Ali terjadi secara langsung dan umum melalui aklamasi setelah terbunuhnya 'Utsman. Ini menggambarkan proses perkembangan baiat yang dinamis pada masanya. Kemudian berkembang dan termetamorfosa dalam praktik pada negara-negara Muslim di dunia.

\section{Baiat dalam Politik Islam Indonesia}

Islam menjadi sebuah agama yang banyak dijadikan sebagai dasar ideologi bagi partai politik, terlebih partai politik yang berasaskan

\footnotetext{
${ }^{23}$ Mahmoud M. Ayoub, The Crisis of Muslim History, 129.
} 
Islam, seperti Partai Persatuan Pembangunan (PPP), Partai Kebangkitan Bangsa (PKB), Partai Amanat Nasional (PAN), dan Partai Keadilan Sejahtera (PKS) sebelumnya bernama Partai Keadilan (PK). ${ }^{24}$ Partaipartai tersebut memiliki anggaran dasar/anggaran rumah tangga (AD/ART) yang berbeda-beda. Ini berakibat pada perbedaan sistem suksesi kepemimpinan dan baiat yang berbeda pula. Begitu juga dengan organisasi sosial kemasyarakatan yang menjadikan Islam sebagai asas mereka, juga memiliki sistem yang berbeda.

Partai Keadilan Sejahtera (PKS) misalnya, sebagai partai politik berasaskan Islam yang mengalami lompatan yang signifikan dari $6,79 \%$ pada pemilu 2014 dan 8,21\% pada pemilu 2019 dianggap sebagai salah satu partai representasi penampung aspirasi umat Islam. Partai ini menjadikan Islam sebagai ideologi,sistem pemikiran, konsep, ide, dan gagasan. Seluruh aktivitas politik yang dibangun menjadi sebuah jalan yang bernilai ibadah bagi orang-orang yang ada di dalamnya. ${ }^{25}$ Oleh karenanya, berpolitik bagi kader PKS bukan hanya sekedar menyampaikan aspirasi, maupun karir organisasi, lebih dari itu, sebuah bantuk ibadah kepada Tuhan.

Suharna Surapranatamenyebut PKS memiliki enam pilar politik yang dijalankan olehnya. Keenam pilar tersebut adalah 1) pendekatan pelayanan diutamakan daripada pendekatan kekuasaan, 2) pengelolaan negara menjadi tanggung jawab bersama, 3) bertanggung jawab dalam kebebasan, 4) Tidak adanya diskriminasi dalam hal keadilan dan kesederhanaan, 5) kemerdekaan yang terbimbing, dan 6) panglima adalah hukum dan undang-undang. ${ }^{26}$ Keenam hal ini menjadi pilar politik yang dikedepankan oleh PKS, dan kesemuanya ada dalam ajaran Islam.

Sama halnya dengan partai politik Islam, organisasi masyarakat Islam (ormas)di Indonesia juga memiliki sistem yang tidak sama satu dengan yang lain. Nahdatul Ulama (NU), Muhammadiyah, AlWashliyah, Nahdlatul Wathan, dan Persis memiliki AD/ART yang berbeda. Artinya, sistem baiat yang ada padanya juga berbeda. Meski

${ }^{24}$ Bahkan sebelumnya ada Partai Syarikat Islam Indonesia (PSII), Partai Umat Islam (PUI), Partai Masyumi Baru, Partai Bulan Bintang (PBB), Partai Keadilan (PK), dan Partai Nahdhatul Ummat (PNU) sebagai akibat dari eforia politik yang tidak terelakkan pasca reformasi 1998.

25 MPP PKS, Platform Kebijakan Pembangunan Partai Keadilan Sejahtera, (Jakarta:2008), 30-32.

${ }^{26}$ Suharna Surapranata, Falsafah Dasar Perjuangan PKS, (MPP PKS, 2007) hal 101 
pada era reformasi saat ini mereka tidak menyatakan diri sebagai organisasi partai politik atau organisasi yang berafiliasi pada partai politik tertentu, namun organisasi-organisasi tersebut mendapatkan tarikan yang cukup kuat dari politik praktis. Ini merupakan sebuah bentuk tantangan termasuk tantangan yang dihadapi oleh Islam. Salah satunya Islam dituntut untuk bersuara moral yang otentik karena persoalan-persoalan kontemporer yang begitu banyak dan ditandai dengan disorientasi nilai dan degradasi moralitas. ${ }^{27}$ Oleh karenanya, setiap ormas Islam dalam perkembangannya selalu memunculkan istilah kembali ke khittah karena berbagai persoalan. Khittah yang dimaksud adalah kembali pada komitmen awal ketika orang-orang yang dipilih dan dibaiat untuk menjalankan organisasinya.

Baiat dalam konteks politik Islam Indonesia lebih terlihat pada saat sumpah jabatan. Baik lembaga eksekutif, legislatif, dan yudhikatif saat mereka dilantik, maka akan disumpah dan janji sesuai dengan agamanya masing-masing sebelum menjalankan jabatannya. Mereka didampingi oleh rohaniawan. Sumpah dan janji inilah yang kemudian dikenal dengan sumpah jabatan. Sumpah jabatan adalah suatu upacara seremonial yang sangat sakral dalam pengangkatan seseorang untuk memangku jabatan yang baru. Ini juga dilakukan oleh lembagalembaga pemerintahan baik eksekutif, legislatif, dan yudhikatif sebelum memangku jabatan secara resmi.

Pada lembaga eksekutif misalnya, dalam hal ini Presiden dan Wakil Presiden, sebelum memangku jabatannya, bersumpah menurut agama, atau berjanji dengan sungguh-sungguh di hadapan Majelis Permusyawaratan Rakyat (MPR) atau Dewan Perwakilan Rakyat (DPR). Sumpah dan janji tersebut berbunyi sebagai berikut :

"Saya berjanji dengan sungguh-sungguh akan memenuhi kewajiban Presiden Republik Indonesia (Wakil Presiden Republik Indonesia) dengan sebaik-baiknya dan seadil-adilnya, memegang teguh Undang-Undang Dasar dan menjalankan segala undangundang dan peraturannya dengan selurus-lurusnya serta berbakti kepada Nusa dan Bangsa". ${ }^{28}$

27 Atang Abd. Hakim dan Jaih Mubarok, Metodologi Studi Islam, (Bandung: Remaja Rosda Karya, 2006), cet. VIII, 5.

${ }^{28}$ Undang - Undang Dasar Negara Republik Indonesia Tahun 1945, Pasal 9 ayat 1. Akan terjadi perbedaan kalimat pada awal dan akhir sumpah yang diucapkan. Apabila Presiden/Wakil Presiden beragama Islam, maka di awali dengan ucapan "Demi Allah". Agama Kristen Protestan/Katolik diakhiri dengan ucapan "Semoga 
Politica, Vol. 7, No. 1, Januari-Juni 2020

Sama halnya dengan eksekutif, pada lembaga legislatif yakni Dewan Perwakilan Rakyat (DPR) mengucapkan sumpah jabatannya. Sumpah dan janji tersebut berbunyi:

"Demi Allah (Tuhan) saya bersumpah/berjanji: bahwa saya, akan memenuhi kewajiban saya sebagai anggota/ketua/wakil ketua Dewan Perwakilan Rakyat dengan sebaik-baiknya dan seadiladilnya, sesuai dengan peraturan perundang-undangan, dengan berpedoman pada Pancasila dan Undang-Undang Dasar Negara Republik Indonesia Tahun 1945; bahwa saya dalam menjalankan kewajiban akan bekerja dengan sungguh-sungguh, demi tegaknya kehidupan demokrasi, serta mengutamakan kepentingan bangsa dan negara daripada kepentingan pribadi, seseorang, dan golongan; bahwa saya akan memperjuangkan aspirasi rakyat yang saya wakili untuk mewujudkan tujuan nasional demi kepentingan bangsa dan Negara Kesatuan Republik Indonesia. "29

Setelah mengakhiri pengucapan sumpah/janji Presiden/Wakil Presiden, DPR, dan MPR menandatangani formulir sumpah/janji yang telah disiapkan. Penandatanganan ini selain sebuah seremonial, juga merupakan salah satu bentuk komitmen awal untuk mengemban amanah yang diberikan oleh rakyat.

Berdasarkan pada uraian yang telah disebutkan sebelumnya, maka dapat diketahui bahwa pada setiap bentuk penyatuan dukungan yang menyangkut dengan kepentingan orang banyak, secara formal diadakan suatu sumpah dan janji setia. Sumpah dan janji setia ini tidak hanya sebagai formalitas hubungan antar manusia saja, namun juga merupakan salah satu bentuk ketaatan kepada Tuhan Yang Maha Esa. Hal ini disebabkan sebagai makhluk Tuhan manusia memiliki tanggung jawab dan kewajiban kepada Tuhan dan alam ciptaan-Nya. Oleh sebab itu, pada setiap bentuk kegiatan baik yang bersifat birokrasi maupun tidak, di Indonesia masih mengedepankan norma-norma keagamaan. Tidak hanya sebagai alat legitimasi, tetapi juga sebagai norma yang harus dipatuhi.

Tuhan menolong saya", Agama Hindu diawali dengan ucapan "Om atah Paramawisesa", dan Budha diawali dengan "Demi Sang Hyang Adi Budha".

${ }^{29}$ Suara Pembaruan, "Ini Isi Sumpah/Janji Anggota DPR Terpilih" dalam https://www.beritasatu.com/nasional/214106/ini-isi-sumpahjanji-anggota-dpr-terpilih (diakses pada tanggal 15 Juli 2019). 
Persamaan ini dapat dilihat antara masa rasulullah dengan masamasa pemerintahan Indonesia. Mulai dari pemerintahan Orde Lama, Orde Baru, reformasi, hingga kini. Kesemuanya menggunakan sumpah dan janji setia dalam setiap bentuk penyatuan dukungan. Jika pada masa Rasul Saw. dikenal adanya baiat atau bai'ah, di Indonesia hal ini lebih dikenal dengan sumpah jabatan.

Pada masa Rasul Saw. dan sahabat, pengangkatan pemimpin harus melalui pemilihan dan ikrar kesetiaan (bai'at), yang dipahami sebagai janji setia yang saling mengikat, ketika sang pemimpin bersumpah untuk hanya menerapkan Al-Quran dan Sunnah, tidak yang lainnya, dan umat bersumpah untuk setia kapadanya. ${ }^{30}$ Baiat yang terjadi pada masa rasul dan sahabat terjadi secara langsung, bahkan terkadang berhadapan antara yang berbaiat dengan yang menerima baiat.

Pada konteks pemerintahan di Indonesia, sumpah dan janji setia ini tidak disebut dengan baiat, melainkan disebut dengang sumpah jabatan. Pemimpin yang terpilih memiliki tanggung jawab dalam memimpin, ia terlebih dahulu bersumpah dan berjanji. Hal ini dilaksanakan secara formal, khususnya pada saat pelantikan pemimpin tersebut. Presiden dan Wakil Presiden, misalnya, bersumpah dan berjanji untuk menjalankan kewajibannya sebagai Presiden dan Wakil Presiden berdasarkan atas undang-undang yang berlaku. Sumpah jabatan ini dilakukan di hadapan Majelis Permusyawaratan Rakyat, serta disaksikan oleh rakyat dan perwakilan negara-negara sahabat.

Jika dalam pernyataan baiat yang terjadi pada masa Rasulullah SAW. tidak akan menyekutukan Allah dan mematuhi Nabi, serta berlandaskan Al-Quran dan Hadis, di Indonesia tidak demikian. Hal ini dikarenakan Indonesia bukan negara Islam, melainkan negara hukum yang berlandaskan Pancasila dan Undang Undang Dasar Tahun 1945. Oleh sebab itulah, dalam pengucapan sumpah dan janji setia itu, diucapkan hanya untuk menjalankan kewajibannya berdasarkan pada undang-undang yang berlaku. Ini pun terjadi pada setiap bentuk pengangkatan atau pelantikan seorang pemimpin, khususnya pemimpin partai politik atau ormas Islam, selalu dilakukan sumpah terlebih dahulu. Dalam sumpahnya, mereka (pemimpin) akan melaksanakan tanggung jawab dan memegang amanah berdasarkan atas peraturan yang berlaku.

\footnotetext{
${ }^{30}$ Antony Black, Pemikiran Politik Islam, 49.
} 
Politica, Vol. 7, No. 1, Januari-Juni 2020

\section{E. Kesimpulan}

Baik pada masa Rasulullah Saw. maupun pada masa-masa yang ada di Indonesia, sama-sama menggunakan baiat sebagai bentuk legitimasi dalam setiap kepemimpinan. Maka, dapat diketahui bahwa baiat masih relevan dengan kondisi politik Islam yang ada di Indonesia. Namun, konsep baiat mengalami modifikasi dalam bentuk sumpah/janji setia. Ini berbeda pada masa Rasul Saw. dan al khulafa ar rasyidun dengan masa-masa yang terjadi di Indonesia. Bila pada masa Rasul Saw. dan al khulafa ar rasyidun janji setia diberikan dari rakyat kepada pemimpin, pada kehidupan saat ini justru sebaliknya, pemimpin yang berucap sumpah dan janji kepada rakyatnya. Secara praktis, penelitian ini menyarankan agar sumpah dan janji setia itu tetap dilanjutkan sebagai sebuah media legitimasi formal. Sedangkan secara teoritis penelitian ini menyarankan agar dilakukan penelitian lebih lanjut dengan pendekatan dan metode yang berbeda. 
Politica, Vol. 7, No. 1, Januari-Juni 2020

\section{Daftar Pustaka}

Abd. Hakim, Atang. dan Mubarok, Jaih.Metodologi Studi Islam. Bandung: Remaja Rosda Karya, 2006. cet. VIII.

Ash Shidieqy, T.M Hasbi.Asas-asasHukum Tata Negara MenurutSyariat Islam. Yogyakarta: MatahariMasa, 1996.

Black, Antony.PemikiranPolitik Islam. Jakarta: Serambi,2006.

Departemen Pendidikan dan Kebudayaan.Kamus Besar Bahasa Indonesia.Jakarta: Balai Pustaka, 1995. cet. IV.

Haikal, Muhammad Husein.Sejarah Hidup Muhammad, Penj. Ali Audah, Jakarta: LiteraAntar Nusa, 2005. cet. XXX.

Ibn Sa'ad, Abu Abdullah Muhammad.Purnama Madinah. Bandung: Al-Bayan, 1997.

Iqbal, Muhammad.Fiqh Siyasah. Jakarta: Gaya Media Pratama, 2007.

Khalid Ibrahim Jindan, Teori Pilitik Islam:Telaah Kritis Ibnu Taimiyah Tentang Pemerintahan Islam. Terj dari judul aslinya The Islamic Theory of Govermen According to IbnTaymiyah.Surabaya: RisalahGusti, 1999.

M. Ayoub, Mahmoud.The Crisis of Muslim History.Bandung: Mizan, 2004.

MPP PKS, Platform Kebijakan Pembangunan Partai Keadilan Sejahtera.Jakarta: TP, 2008.

Suhelmi,Ahmad.Pemikiran Politik Barat: Kajian Sejarah Perkemabangan Pemikiran Negara, Masyarakat, dan Kekuasaan.Jakarta: PT. Gramedia Pustaka, 2001. cet. II.

Surapranata, Suharna.Falsafah Dasar Perjuangan PKS. MPP PKS, 2007. 